Gournal of Science
http://dergipark.gov.tr/gujs

\title{
Chemical Composition and Antibacterial Activities of Ethanol Extract of Geodorum attenuatum Griff. (Orchidaceae)
}

\author{
Hong Thien $\mathrm{VAN}^{1}$ (D), Thi Ngan Ha BUI ${ }^{1}$ (D) Yen Hoa MAI $^{1}$ (D) Minh Nhat Hao NGUYEN $^{1}$ Tan Viet PHAM $^{1}$ \\ (D), Van Son $\mathrm{LE}^{2}$ (D), Van Dat DOAN ${ }^{3}$, Pham Tan Quoc LE ${ }^{*}$ (D) \\ ${ }^{l}$ Institute of Biotechnology and Food Technology, Industrial University of Ho Chi Minh City, No. 12 Nguyen Van Bao, Ward 4, Go Vap District, \\ Ho Chi Minh City, Vietnam \\ ${ }^{2}$ Binh Chau-Phuoc Buu Nature Reserve, Bung Rieng ward, Xuyen Moc District, Ba Ria-Vung Tau Province, Vietnam \\ ${ }^{3}$ Faculty of Chemical Engineering, Industrial University of Ho Chi Minh City, No. 12 Nguyen Van Bao, Ward 4, Go Vap District, Ho Chi Minh \\ City, Vietnam

\section{Highlights} \\ - This paper focuses on chemical compounds and antibacterial activity of G. attenuatum tuber. \\ - Liquid chromatography mass spectrometry and the antibacterial assay are applied. \\ - The specimen contained nine chemical compounds and could inhibit six tested bacteria.
}

\section{Article Info}

Received: 04/01/2020

Accepted: $27 / 03 / 2020$

\begin{tabular}{l} 
Keywords \\
\hline Antibacterial activity \\
G. attenuatum \\
Chemical composition \\
Ethanol extract \\
LC-MS
\end{tabular}

\section{INTRODUCTION}

Geodorum Jack., belonging to Orchidaceae family is a genus of only about 10 species occurring primarily in temperate regions of Asia, Australia and in the Southeast Pacific islands [1]. Several studies indicated the potential application of species of this genus in medicine. The phytochemical composition, antimicrobial and other bioactivities of the compounds extracted from several plants of Geodorum genus have been shown by many recent studies [2,3]. In Vietnam, six species of the Rothmannia genus were recorded such as $G$. attenuatum, $G$. densiflorum, $G$. pulchellum, $G$. recurvum, $G$. siamense and $G$. citrinum [4-7].

Geodorum attenuatum Griff. was described for the first time by Griffith [8]. To date, G. attenuatum has been found in Thailand, China, India and Vietnam [1,7,9]. In Vietnam, following Pham-Hoang (2000) [7], the species has been found in Hue, Gia Lai, Kon Tum, Tay Ninh Provinces and Hai Phong City. Recently, G. attenuatum was recorded in Binh Chau-Phuoc Buu Nature Reserve, Ba Ria-Vung Tau Province, Vietnam by Bui et al. (2019) [10], who was the second coauthor of this paper. Currently, the number of studies about this species is limited and its bioactivity is still unknown. 
Accordingly, the research on chemical composition and bioactivity of G. attenuatum extract becomes the important step for wider application and value improvement of this species. In this study, the phytochemical composition and antibacterial activity of ethanol extract of G. attenuatum tuber were firstly determined, subsequently, provided more information for further application of this species.

\section{MATERIALS AND METHOD}

\subsection{Plant Materials}

Specimens of G. attenuatum were collected from Binh Chau-Phuoc Buu Nature Reserve, Bung Rieng ward, Xuyen Moc District, Ba Ria-Vung Tau Province, location of about 10 32 '51”N; 107 31'35”E, July 4, 2018, $48 \mathrm{~m}$ in elevation (Figure 1).
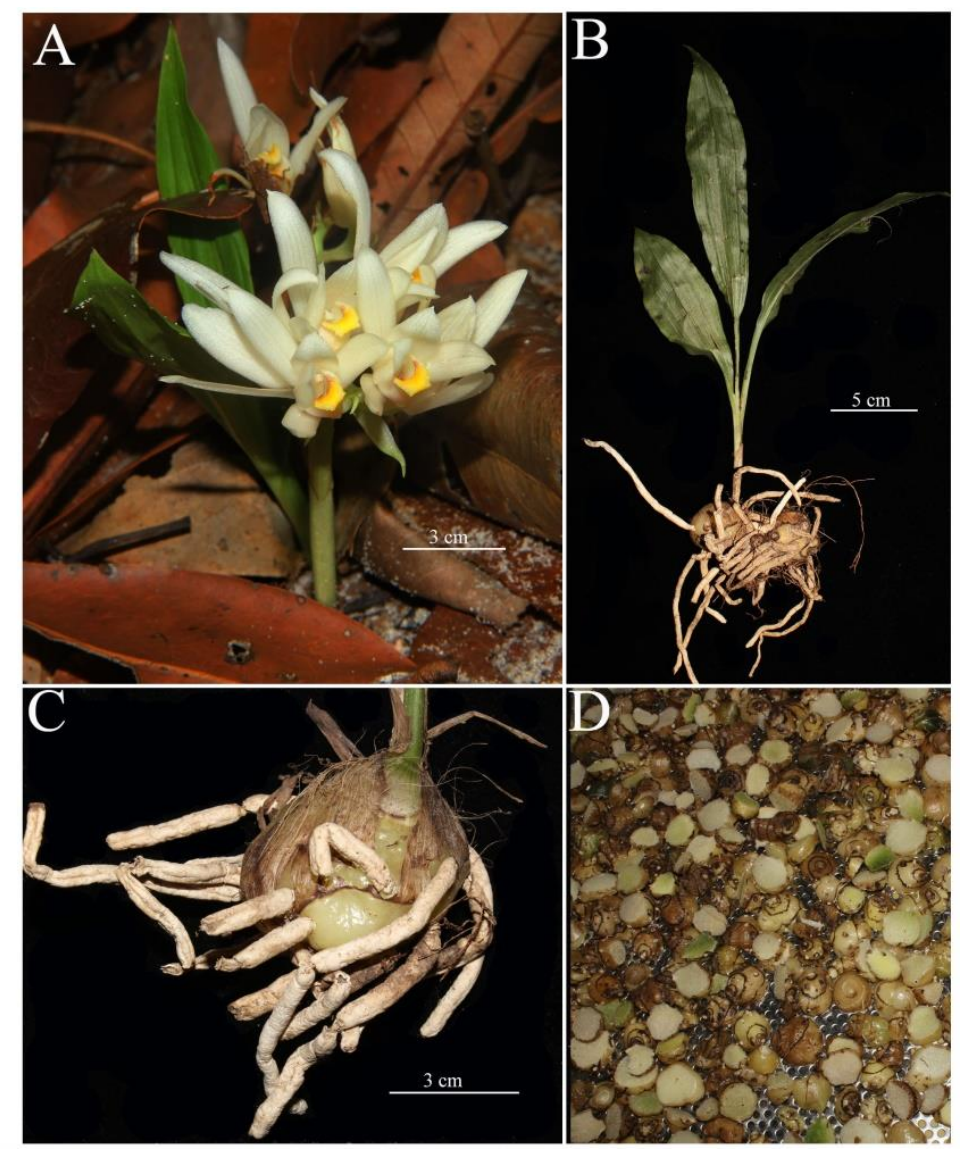

Figure 1. Geodorum attenuatum: A. Habitat; B. Leaf; C. Tuber; D. Dried tubers

\subsection{Bacterial Strains}

Six bacterial strains were used to determine the antibacterial activity of ethanol extract from G. attenuatum. Two Gram-positive bacteria, including Bacillus cereus (ATCC 11774), Staphylococcus aureus (ATCC 25923), and four Gram-negative bacteria, including Escherichia coli (ATCC 25922), Pseudomonas aeruginosa (ATCC 27853), Salmonella enteritidis (ATCC 13976) and Salmonella typhimurium (ATCC 13311) were obtained from the microbiology collection, Department of Biotechnology, Institute of Food and Biotechnology, Industrial University of Ho Chi Minh city, Viet Nam. All bacterial strains were maintained at $-20^{\circ} \mathrm{C}$ in $20 \%$ glycerol solution and inoculated into Luria-Bertani broth at $37^{\circ} \mathrm{C}$ for $24 \mathrm{~h}$ to be re-activated again before using in further experiments. 


\subsection{Extraction Procedure}

Fresh sliced tubers were dried at a $50^{\circ} \mathrm{C}$ until constant weight and grounded into medicinal powder. $100 \mathrm{~g}$ of the resulting powder was soaked in $1000 \mathrm{~mL}$ of $99 \%$ ethanol for 7 days at room temperature and filtered to collect the extract. The extract was then condensed under vacuum pressure at $60^{\circ} \mathrm{C}$ to obtain the brown medicinal paste, according to Altemimi et al. (2017) To ensure the absolute absence of ethanol in the paste, sublimation dryer was utilized [11].

\subsection{Liquid Chromatography Mass Spectrometry (LC-MS)}

The LC-MS analysis of extract was performed on HPLC Agilent 1200 infinity liquid chromatography system (Agilent Technologies, CA, USA) coupled with MicroTOF-QII mass spectrometer (Bruker Daltonics, Germany). In brief, aliquots of ethanol extract were injected to HPLC Agilent 1200 infinity liquid chromatography system and then the chromatographic separation was carried out using an ACE3$\mathrm{C}_{18}$ analytical column $(4.6 \times 150 \mathrm{~mm}, 3.5 \mu \mathrm{m})$ at $40^{\circ} \mathrm{C}$ as a stationary phase. The mobile phase consisted of deionized water with $0.1 \%$ formic acid as solvent $\mathrm{A}$ and acetonitrile with $0.1 \%$ formic acid as solvent $\mathrm{B}$. The gradient elution program for the chromatographic separation (Table 1) was set as following conditions: 90 solvent A:10 solvent B (0-15min), 0 solvent A:100 solvent B (15-30 min), 90 solvent A:10 solvent B (31-40 $\mathrm{min}$ ) at the flow rate of $0.3 \mathrm{~mL} / \mathrm{min}$. The mass spectrometer was implemented with electrospray ionization source (ESI) at positive mode and mass spectra data were recorded in a mass range $50-2000 \mathrm{~m} / \mathrm{z}$. Data analysis was performed using Data Analysis software (Bruker, Germany).

Table 1. Gradient elution program for the chromatographic separation

\begin{tabular}{|l|l|l|}
\hline Time (min) & Solvent A* & Solvent B* \\
\hline 0 & 90 & 10 \\
\hline 15 & 0 & 100 \\
\hline 30 & 0 & 100 \\
\hline 31 & 90 & 10 \\
\hline 40 & 90 & 10 \\
\hline
\end{tabular}

(*): presented as the percentage of volume of mobile phase

\subsection{Antibacterial Activities}

The antibacterial assay of ethanol extract of G. attenuatum tuber was conducted using the method detailly described by Bauer et al. (1996) [12]. The bacteria were inoculated in LB Broth until a turbidity of 0.5 McFarland standards was reached. Subsequently, $100 \mu \mathrm{L}$ bacterial suspensions was spread on sterile Mueller Hinton plate and a sterile $6 \mathrm{~mm}$ diameter discs were put on the inoculated surface. $20 \mu \mathrm{L}$ of the sample was added onto each disc and the plates were maintained at $4^{\circ} \mathrm{C}$ for 2 hours to allow extract diffusion into the medium. The plates were kept at $37^{\circ} \mathrm{C}$ for $24 \mathrm{~h}$ and the antibacterial activity of sample was determined via the inhibition zone diameter of tested bacteria. Sterilize distilled water was used as negative control and Gentamycin antibiotic discs (supplied by Nam Khoa BioTek, Viet Nam) were used as positive control.

\subsection{Data Analysis}

The one-way analysis of variance (ANOVA) method was used to analyze the results. Fisher's least significant difference (LSD) procedure using Statgraphics software (Centurion XV) was the method to determine significant differences among the means from triplicate analyses at $(p<0.05)$. The data were expressed as a mean \pm standard deviation (SD). 


\section{RESULTS AND DISCUSSIONS}

\subsection{Phytochemical Analysis}

In this study, mass spectra of compounds which identified in the ethanol extract of G. attenuatum tuber were compared with previous studies about chemical composition of species of Orchidaceae family. As presented in Table 2 and Figure 2, 9 compounds in ethanol extract of G. attenuatum tuber were found, such as Disaccharide, Oxoheneicosanoic acid, Shikimic acid, Chlorogenic acid, 1-Oleoyl-2-acetyl-glycerol, Azafrin, 5,6,7-trihydroxyfavone, 2,3-isopropylidene-1-oleoyl-glycerol, 2,3-isopropylidene-1-oleoylglycerol and trans-Docosanoyl ferulate.

Disaccharide, a type of carbohydrate, has important roles in the human diets and many bioactivities. Genova et al. (2004) have proved disaccharides, such as sucrose, trehalose influenced the bending elasticity of SOPC (1-stearoyl-2-oleoyl-sn-glycero-3-phosphocholine) lipid membranes [13]. Shikimic acid was first isolated from fruits of aniseed (Illicium anisatum) by Eykman which is the known precursor of aromatic amino acids, L- phenylalanine, and L-tyrosine [14]. The shikimic acid biosynthesis pathways were operated in leaves or fruit of many plants and also in microorganisms, but not in humans or animals. Consequently, they are considered essential nutritive compounds in the human nutrition $[15,16]$.

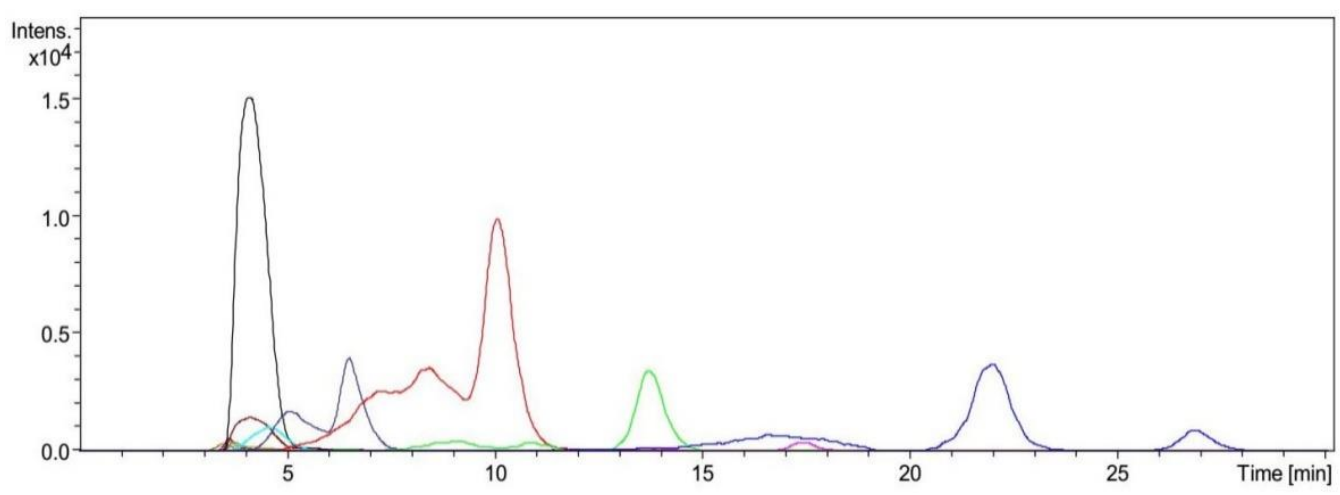

Figure 2. Chromatogram (LC-MS) of the ethanol extract of $G$. attenuatum tuber obtained by maceration

Table 2. Phytochemical composition of ethanol extract of G. attenuatum tuber

\begin{tabular}{|l|l|l|l|}
\hline No. & Compounds & Formula & References \\
\hline 1 & Disccharide & $\mathrm{C}_{12} \mathrm{H}_{22} \mathrm{O}_{11}$ & {$[17]$} \\
\hline 2 & Oxoheneicosanoic acid & $\mathrm{C}_{21} \mathrm{H}_{40} \mathrm{O}_{3}$ & {$[17]$} \\
\hline 3 & Shikimic acid & $\mathrm{C}_{7} \mathrm{H}_{10} \mathrm{O}_{5}$ & {$[17]$} \\
\hline 4 & Chlorogenic acid & $\mathrm{C}_{16} \mathrm{H}_{18} \mathrm{O}_{9}$ & {$[17]$} \\
\hline 5 & Azafrin & $\mathrm{C}_{27} \mathrm{H}_{38} \mathrm{O}_{4}$ & {$[17]$} \\
\hline 6 & $5,6,7-$ trihydroxyfavone & $\mathrm{C}_{15} \mathrm{H}_{10} \mathrm{O}_{5}$ & {$[17]$} \\
\hline 7 & 1-Oleoyl-2-acetyl-glycerol & $\mathrm{C}_{23} \mathrm{H}_{42} \mathrm{O}_{5}$ & {$[18]$} \\
\hline 8 & 2,3-isopropylidene-1-oleoyl-glycerol & $\mathrm{C}_{24} \mathrm{H}_{44} \mathrm{O}_{4}$ & {$[18]$} \\
\hline 9 & trans-Docosanoyl ferulate & $\mathrm{C}_{32} \mathrm{H}_{54} \mathrm{O}_{4}$ & {$[19]$} \\
\hline
\end{tabular}

Chlorogenic acid, belonging to the hydroxycinnamic acid group, is one of the most available phenolic acid compounds in foods, such as coffee and tea. Many in vivo studies showed the role of chlorogenic acid as a nutraceutical for the prevention and treatment of metabolic syndrome and associated disorders [20,21]. For instance, chlorogenic acid has an effect on body weight, body fat, and obesity-related hormones of induced-obese imprinting control region mice. Azafrin - a natural carotenoid isolated from the root of 
Centranthera grandiflora, a Chinese ethnomedicine, has been widely used to treat cardiovascular diseases in China. Azafrin has protected cardiomyocytes by reducing oxidative stress [22].

5,6,7-trihydroxyfavone, belonging to the flavones, was first isolated from Scutellariae baicalensis. Previous studies showed that 5,6,7-trihydroxyfavone has beneficial effects on health, such as anti-oxidant, anti-viral, anti-thrombotic, and anti-inflammatory effects [23]. Fu (2012) demonstrated that 5,6,7trihydroxyfavone improved hyperglycemia, glucose tolerance, and blood insulin levels in high-fat diet diabetic mice [24]. Christina et al. (2005) showed the role of 1-Oleoyl-2-acetyl-glycerol in Vitro condition. For instance, it is used as an agonist for human polymorphonuclear leukocytes [25]. Moreover, 1-Oleoyl2-acetyl-glycerol stimulates 5-Lipoxygenase activity, a compound that catalyzes the formation of corresponding hydroperoxides from polyunsaturated fatty acids [26].

\subsection{Antibacterial Activity}

Table 3. The inhibition zone of ethanol extract of G. attenuatum tuber against six tested bacteria. (-): No inhibition

\begin{tabular}{|l|l|l|l|l|}
\hline \multirow{2}{*}{ Tested bacteria } & \multicolumn{4}{l|}{ Growth inhibition zone $(\mathrm{mm})$} \\
\cline { 2 - 5 } & Original extract & $\begin{array}{l}\text { Diluted extract } \\
(1: 2)\end{array}$ & $\begin{array}{l}\text { Diluted extract } \\
(1: 4)\end{array}$ & $\begin{array}{l}\text { Diluted extract } \\
(1: 6)\end{array}$ \\
\hline S. aureus & $14.0 \pm 1.0^{\mathrm{b}}$ & $8.0 \pm 0.5^{\mathrm{a}}$ & $7.7 \pm 0.3^{\mathrm{a}}$ & $8.2 \pm 0.8^{\mathrm{a}}$ \\
\hline B. cereus & $7.5 \pm 0.5^{\mathrm{a}}$ & $7.7 \pm 0.3^{\mathrm{a}}$ & $7.7 \pm 0.3^{\mathrm{a}}$ & $7.5 \pm 0.0^{\mathrm{a}}$ \\
\hline S. enteritidis & $8.2 \pm 0.3^{\mathrm{b}}$ & $8.0 \pm 0.5^{\mathrm{b}}$ & $7.2 \pm 0.3^{\mathrm{a}}$ & - \\
\hline S. typhimurium & $8.2 \pm 0.3^{\mathrm{b}}$ & $8.0 \pm 0.5^{\mathrm{b}}$ & $8.0 \pm 0.3^{\mathrm{b}}$ & $7.2 \pm 0.3^{\mathrm{a}}$ \\
\hline E. coli & $8.2 \pm 0.3^{\mathrm{b}}$ & $7.9 \pm 0.3^{\mathrm{ab}}$ & $7.5 \pm 0.5^{\mathrm{a}}$ & $7.9 \pm 0.3^{\mathrm{ab}}$ \\
\hline P. aeruginosa & $8.2 \pm 0.3^{\mathrm{a}}$ & $8.2 \pm 0.8^{\mathrm{a}}$ & $8.0 \pm 0.5^{\mathrm{a}}$ & - \\
\hline
\end{tabular}

Different lowercase letters in the same row denote significant differences between various extracts $(p<0.05)$.
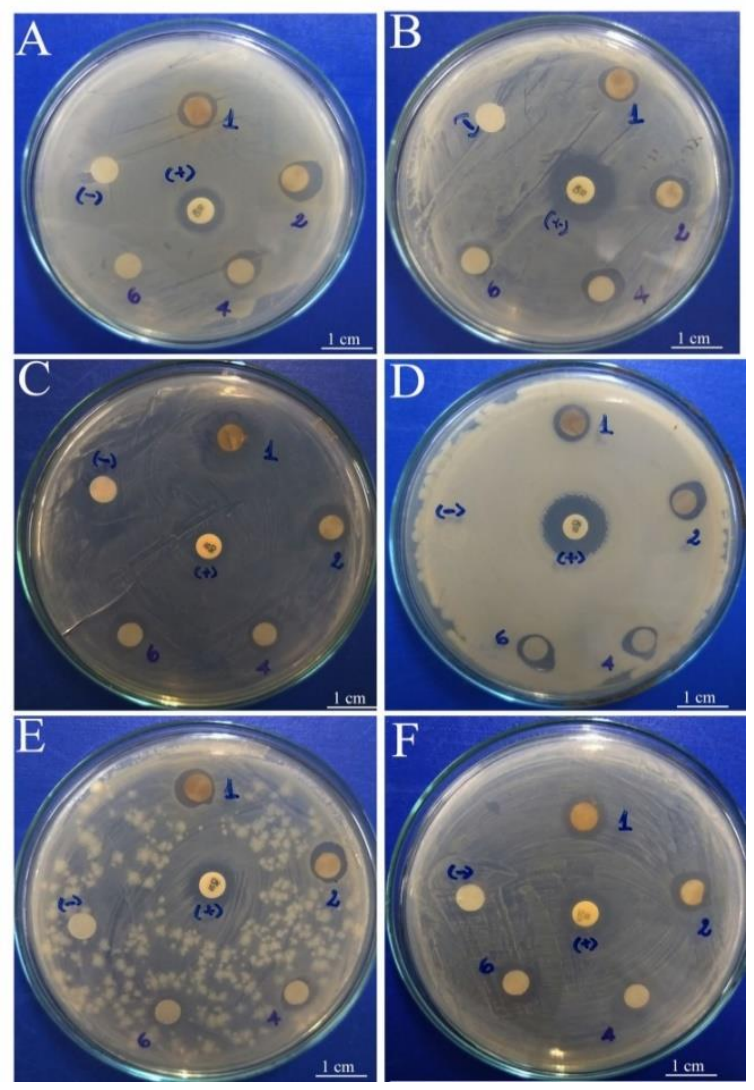

Figure 3. Antibacterial activity of ethanol extract of $G$. attenuatum tuber against tested bacteria. $P$. aeruginosa (A), S. typhimurium (B), S. aureus $(C)$, B. cereus $(D)$, S. enterritidis $(E)$, E. coli $(F)$. The paper 
discs numbered as 1, 2, 4, 6 were loaded with original extract, two-fold four-fold, and six-fold diluted extracts, respectively. (-) Negative control with sterilized distilled water, (+) Positive control with discs containing gentamicin

Data stated in Table 3 and Figure 3 showed that the ethanol extract of G. attenuatum tuber was able to resist against six bacteria studied. In general, zones of inhibition were completely transparent in the six bacteria, such as B. cereus, E. coli, P. aeruginosa, S. enterritidis, S. typhi, S. aureus. However, diameters of inhibition zones were various in different bacterial strains and dilution factors. Among six tested bacteria strains, the original ethanol extract showed the highest inhibitory effect on Staphylococus aureus $(14 \mathrm{~mm})$, followed by $E$. coli, $S$. typhimurium, $S$. enteritidis $P$. aeruginosa $(8.2 \mathrm{~mm})$ and $B$. cereus $(7.5 \mathrm{~mm})$. All six tested bacteria strains, the increase of dilution ratio of the extract as 1:2, 1:4 or 1:6 resulted in the decrease of antibacterial and in case of Salmonella enteritidis and Pseudomonas aeruginosa, no inhibitory effect was observed in diluted extract $(1: 6)$.

As aforesaid in the introduction, this is the first research showing the phytochemical composition and the antibacterial activity of ethanolic extract from the tuber of $G$. attenuatum. However, certain previous studies showed the antibacterial and antifungal activities of different extract from species belonging to genus Geodorum. For instance, Akter et al. (2010) proved the water, methanol and petroleum ether extracts from the pseudobulb of $G$. densiflorum were able to resist against 5 Gram-positive bacteria, 8 Gram-negative bacteria and 3 fungal strains studied [27]. In another study, Keerthiga and Anand (2014) demonstrated that various extracts of $G$. densiflorum was able resist against 6 bacterial strains, including Bacillus subtilis, Staphylococcus aureus, Streptococcus pyogenes, Escherichia coli, Pseudomonas aeruginosa, and Klebseilla pneumonia [2]. Similarly, Keerthiga and Anand (2015) showed that water, ethanol and chloroform extracts of $G$. densiflorum were resistant to 4 fungal strains, such as Penicillium chrysogenum, Aspergillus niger, Rhizoctonia solani and Colletotrichum falcatum [3].

\section{CONCLUSION}

In this stuy, 9 compounds were firstly identified in ethanol extract of $G$. attenuatum tuber by LC-MS method. The antimicrobial activity of the ethanol extract against six bacterial strains, including Bacillus cereus, Staphylococcus aureus, Escherichia coli, Pseudomonas aeruginosa, Salmonella enteritidis, and Salmonella typhimurium was demonstrated. The result of this study might be a platform for further application of $G$. attenuatum.

\section{CONFLICTS OF INTEREST}

No conflict of interest was declared by the authors.

\section{REFERENCES}

[1] Chen, X., Phillip, J.C., Stephan, W.G., “Geodorum”, Flora of China, 25:258-260, (2009).

[2] Keerthiga, M., Anand, S.P., “Antifungal Activity of Geodorum densiflorum (Lam.) Schltr. against Pathogenic Fungi", American Journal of Phytomedicine and Clinical Therapeutics, 2:1456-1461, (2014).

[3] Keerthiga.M., Anand, S.P., "Anti-infective and anti-biofilm activity of Geodorum densiflorum (Lam.) Schltr. against Methicillin resistant and sensitive Staphylococcus aureus", Advances in Applied Science Research, 6:43-46, (2015).

[4] Averyanov, L.V., Averyanova, A.L., "Updated checklist of the Orchids of Vietnam", Vietnam National University Publishing House, Hanoi, Vietnam, (2003).

[5] Huyen, D.D., "A New Record for the Flora of Vietnam: Geodorum citrinum Jacks. (Orchidaceae)", Gardens’ Bulletin Singapore, 61:45-48, (2009). 
[6] Nguyen, T.B., Averyanov L., Dương, D.H., "Orchidaceae. Checklist of the flora of Vietnam", Agricultural Publishing House, Ha Noi, Vietnam, (2005).

[7] Pham-Hoang, H. Araceae. In: Pham-Hoang H. (ed.), "Cây cỏ Việt Nam: An Illustrated Flora of Vietnam”, Youth Publishing House, Ho Chi Minh City, Vietnam, (2000).

[8] Griffith, W., "Geodorum", Calcutta Journal of Natural History, and Miscellany of the Arts and Sciences in India, 5:385-390, (1845).

[9] Kumar, P., Rawat G.S. Jalal, J.S., "Geodorum attenuatum Griff. (Orchidaceae), a new record from India", Richardiana, 8:80-87, (2008).

[10] Bui, T.N.H., Mai, Y.H., Nguyen, M.N.H., Nguyen, N.T., Le, V.S., Trinh, N.N., Van, H.T., "New distribution in Vietnam and identification of DNA barcode sequence for Geodorum attenuatum (Orchidaceae)", Journal of Agricultural and Rural Development, 5:67-73, (2019).

[11] Altemimi, A., Lakhssassi, N., Baharlouei, A., Watson, D.G., "Phytochemicals: Extraction, Isolation, and Identification of Bioactive Coumpounds from Plant Extracts", Plants, 6:1-23, (2017).

[12] Bauer, A.W., Kirby, W.M., Sherris, J.C., Turck, M., “Antibiotic susceptibility testing by a standardized single disk method”, The American Journal of Clinical Pathology, 45:493-436, (1996).

[13] Genova, J., Zheliaskova, A., Mitov, M.D., "Monosaccharides (fructose, glucose) and disaccharides (sucrose, trehalose) influence the elasticity of SOPC membranes", Journal of Optoelectronics and Advanced Materials, 9:427-430, (2007).

[14] Eykman, J.F., "Sur les principes constituants de l'Illicium religiosum”, Recueil des Travaux Chimiques des Pays-Bas, 4:32-54, (1885).

[15] Aldesuquy, H.S., Ibrahim. A.H.A., "The role of shikimic acid in regulation of growth, transpiration, pigmentation, photosynthetic activity and productivity of Vigna sinensis plants", Phyton, 40:277-292, (2000).

[16] Amalia, M.E., Ramon,J.E., "A short overview on the medicinal chemistry of (-)-shikimic acid”, MiniReviews In Medicinal Chemistry, 12:1443-1454, (2012).

[17] Anna, J.B., Izabela, J.M., Anna, P., Emilia, S., Pawel, K., "The chemical composition of the floral extract of Epipogium aphyllum Sw. (orchidaceae): a clue for their pollination biology", Archives of Biological Science Belgrade, 66:989-998, (2014).

[18] Mariza, G.R., Aparecida, D. Volker, B. Maria do Carmo E. Amaral, Anita J. Marsaioli., "The Chemistry of Flower Rewards-Oncidium (Orchidaceae)", Journal of the Brazilian Chemical Society, 11:600-608, (2000).

[19] Pathrapa, R., Boonchoo, S., Kittisak, L., "Chemical Constituents of Dendrobium williamsoni", Pharmacognosy Journal, 6:36-41, (2014).

[20] Shigetada, F., Takuya, F., Michio, S., Masanori, I., Yukio, Y., Yoshimitsu, N., Osamu, N., Makoto, M., Morihiro, M., Iichiro, S.," Increased oxidative stress in obesity and its impact on metabolic syndrome", Journal of Clinical Investigation, 114:1752-1761, (2004).

[21] Kassi, E., Pervanidou, P., Kaltsas, G., Chrousos, G. Metabolic syndrome., "Definitions and controversies", BMC Medicine, 5:35-48, (2011). 
[22] Yanga, S., Chou, G., Li, Q., "Cardioprotective role of azafrin in against myocardial injury in rats via activation of the Nrf2-ARE pathway", Phytomedicine, 47:12-22, (2018).

[23] Wang, J., Wang, L., Lou, G.H., Zeng, H.R., Hu, J., Huang, Q.W., Peng, W., Yang, X.B., “Coptidis Rhizoma: a comprehensive review of its traditional uses, botany, phytochemistry, pharmacology and toxicology", Pharmaceutical Biology, 57:193-225, (2019).

[24] Fu, Y. "Baicalein, A novel anti-diabetic compound", Master's degree, Virginia Polytechnic Institute and State University, Blacksburg, Virginia, America, (2012).

[25] Christina, H., Dana, A., Lutz, F. Olof Radmark, Dieter Steinhilber., Oliver Werz., "1-Oleoyl-2acetylglycerol Stimulates 5-Lipoxygenase Activity via a Putative (Phospho) lipid Binding Site within the N-terminal C2-like Domain”, Journal of Biological Chemistry, 280:26913-26921, (2005).

[26] Mashima, R., Okuyama, T., "The role of lipoxygenases in pathophysiology; new insights and future perspectives", Redox Biology, 6:297-310, (2015).

[27] Akter, S., Imam, M., Akter, T., "Antimicrobial activity of different extracts of Geodorum densiflorum (Lam) Schltr. Pseudobulb”, Stamford Journal of Pharmaceutical Sciences, 3:47-48, (2010). 